\title{
Nilai yang Dirasakan Dari Produk Sepatu dan Niat Pembelian Kembali Konsumen
}

\author{
Rika Isti Aisyah ${ }^{1 *}$ dan Tintin Suhaeni ${ }^{2}$ \\ ${ }^{1}$ Jurusan Administrasi Niaga, Politeknik Negeri Bandung, Indonesia \\ 2 Jurusan Administrasi Niaga, Politeknik Negeri Bandung, Indonesia
}

\begin{abstract}
:
The concept of perceived value has become a key to gain a competitive advantage to retain consumer in long term. The purpose of this study is to identify how much influence given by perceived value to repurchase intention of shoe product to consumer of PT Ganesha Brodo Indonesia in Bandung. This research was conducted on 100 respondents with purposive sampling technique and analyzed using descriptive method. From result of research shows that Brodo delivering superior consumer value that can enables a firm to achieve favorably repurchase intentions equal to $47,3 \%$.
\end{abstract}

Keywords: consumer, perceived value, repurchase intention

\begin{abstract}
Abstrak:
Konsep nilai yang dirasakan telah menjadi kunci untuk mendapatkan keunggulan kompetitif untuk mempertahankan konsumen dalam jangka panjang. Tujuan dari penelitian ini adalah untuk mengidentifikasi seberapa besar pengaruh yang diberikan oleh nilai yang dirasakan terhadap niat pembelian kembali produk sepatu kepada konsumen PT Ganesha Brodo Indonesia di Bandung. Penelitian ini dilakukan pada 100 responden dengan teknik purposive sampling dan dianalisis menggunakan metode deskriptif. Dari hasil penelitian menunjukkan bahwa Brodo memberikan nilai konsumen superior yang dapat memungkinkan perusahaan untuk mencapai niat pembelian kembali yang baik sebesar $47,3 \%$.
\end{abstract}

Kata Kunci: konsumen, nilai yang dirasakan, niat pembelian kembali

\section{Pendahuluan}

Industri ekonomi kreatif di Indonesia memiliki perkembangan bisnis yang berpeluang untuk meningkatkan perekonomian nasional. Industri kreatif fashion menjadi salah satu dari sektor ekonomi kreatif yang memiliki kontribusi terbesar kedua setelah aplikasi dan game developer. Adapun produk dari sektor fashion yang diproduksi berupa pakaian, alas kaki, dan aksesoris mode lainnya (Wikipedia, 2018).

Perkembangan bisnis pada kelompok pakaian dan alas kaki terus menurun dari angka 6,57\% hingga 2,91\% yang dilansir dari data Badan Pusat Statistik (BPS) selama tahun 2014 s.d 2016. Hal ini merupakan tantangan bagi perusahaan di bidang fashion untuk tetap menjaga eksistensinya dalam upaya meningkatkan perekonomian nasional. Adanya penurunan kinerja industri dan konsumsi masyarakat akan barang dari kulit dan alas kaki tersebut akan menyebabkan pengusaha di bidang ini harus memahami perilaku konsumen yang seringkali berubah. Kebutuhan konsumen menjadi sangat bervariatif seiring dengan perubahan tren fashion yang berbeda seiring waktu.

Gaya hidup terus mengalami perubahan dan akan memengaruhi kebutuhan dalam pemenuhan aktuliasasi diri saat pemilihan produk fashion yang mengikuti tren. Perilaku konsumen ini muncul oleh 
adanya persepsi. Menurut Hawkins dan Mothersbaugh (2010) dalam pemilihan produk seorang konsumen akan mengalami proses pemaparan dan perhatian hingga interpretasi terhadap stimuli pemasaran yang disebut sebagai persepsi. Persepsi dipengaruhi oleh beberapa aspek lingkungan seperti kebiasaan konsumen, pengharapan, selektivitas, masalah kebutuhan dan keinginan, serta kemampuan uang dalam memenuhi keinginannya (Saladin, 2005).

Persepsi dapat digunakan untuk menciptakan nilai pada konsumen sehingga pemasar dapat meningkatkan ketahanan pelanggan yang lebih tinggi. Dalam perspektif ritel menurut Harnett (dalam Sweeney dan Soutar, 2001) apabila pemasar dapat memenuhi kebutuhan berdasarkan persepsi konsumen, pemasar sedang menghantarkan nilai dan menempatkan posisinya jauh lebih kuat dari kompetitor lainnya dalam jangka panjang.

Brodo merupakan perusahaan yang menjual produk fashion khususnya barang dari kulit dan alas kaki dirancang bagi pria aktif dan dinamis. Saat ini perusahaan Brodo melakukan strategi pemasaran dengan memaksimalkan penjualan melalui online juga offline store. Menurut data internal Brodo melalui hasil wawancara prapenelitian (2018) diketahui perbandingan pendapatan dari penjualan Brodo seluruh Indonesia melalui online sebesar 60\% dan offline sebesar 40\% sejak tahun 2012 hingga 2017. Bahkan pada saat ini di tahun 2018 penjualan hampir berbanding lurus online sebesar 55 persen dan offline sebesar 45 persen. Apabila ditinjau pada perbandingan hasil penjualan tersebut, konsumen masih kurang berminat untuk membeli ulang sepatu melalui offline store.

Perusahaan telah berupaya dalam meningkatkan repurchase intention pada tahun 2015 hingga 2016 pemberian diskon 50\% untuk konsumen yang memiliki kartu keanggotaan bila telah melakukan pembelian sebanyak lima kali. Selain itu, target perusahaan dalam mencapai keberhasilan pembelian ulang produknya sebesar $100 \%$ tidak terpenuhi, hal ini disebabkan oleh perubahan persepsi nilai konsumen. Pada hasil data prapenelitian yang dilakukan pada 20 responden, terdapat sebanyak $25 \%$ konsumen tidak tertarik melakukan pembelian ulang yang disebabkan oleh kurangnya penerimaan persepsi nilai yang ingin disampaikan oleh perusahaan pada konsumen. Dengan demikian, perusahaan perlu meningkatkan minat konsumen untuk melakukan pembelian ulang produk dengan memperhatikan aspek persepsi nilai.

Perusahaan sudah melakukan penghantaran nilai lebih pada produk dari segi kualitas (handmade), harga (Rp 250.000 hingga Rp 950.000), emosional (menguatkan komunikasi antar konsumen dengan penjaga toko), dan sosial (desain batik Indonesia "Parang series" pada sol sepatu) untuk dapat menarik minat beli ulang, tapi hal ini dapat berjalan dengan optimal tergantung pada perceived value (persepsi nilai yang dirasakan) oleh konsumen dalam memenuhi kebutuhan konsumen akan produk tersebut.

Terbentuknya persepsi yang tepat pada konsumen akan berdampak pada kesan yang dirasakan dan nilai yang diberikan pula (Suyani, 2013). Berdasar persepsi inilah konsumen akan tertarik dan membeli. Repurchase intention berfokus pada perilaku konsumsi sehingga perusahaan perlu memperhatikan hal ini untuk memahami dan memprediksi bagaimana pelanggan akan berperilaku di masa depan (Ahmed, 2014). Perusahaan akan mendapatkan keuntungan setelah mengetahui nilai yang dirasakan oleh konsumen akan produk yang dibelinya.

Maka dilakukan wawancara prapenelitian kepada dua puluh orang responden mengenai perceived value terhadap repurchase intention (minat beli ulang). Konsumen memberikan respon pada persepsi nilai yang dirasakan pada aspek emosional (EV), sosial (SV), kualitas (QV), dan juga harga (PV) pada tabel 1.

Tabel 1. Data Prapenelitian

\begin{tabular}{|c|c|c|c|c|}
\hline \multirow{2}{*}{ Keterangan } & \multicolumn{4}{|c|}{ Perceived Value } \\
\cline { 2 - 5 } & EV & SV & QV & PV \\
\hline SS & 8 & 3 & 6 & 4 \\
\hline S & 9 & 3 & 11 & 5 \\
\hline N & 3 & 9 & 3 & 13 \\
\hline TS & 0 & 1 & 0 & 2 \\
\hline STS & 0 & 0 & 0 & 0 \\
\hline
\end{tabular}


Berdasarkan tabel 1 dapat diketahui bahwa nilai yang dirasakan konsumen memiliki berbeda-beda di setiap aspek. Price Value memiliki poin yang rendah karena didapatkan hasil netral pada 13 responden, hal ini mengindikasikan bahwa mayoritas konsumen yang membeli sepatu melalui Brodo Offline Store Bandung merasakan adanya perbedaan harga. Hal tersebut penting diperhatikan oleh perusahaan.

\section{Kajian Literatur}

\subsection{Perceived Value}

Perilaku konsumen seringkali mengalami perubahan-perubahan dalam pemenuhan kebutuhannya, oleh sebab itu produsen harus mengantisipasi perubahan yang terjadi. Sikap konsumen perlu dipahami oleh perusahaan dalam mengevaluasi kegiatan pemasaran dan meramalkan perilaku konsumen. Hal ini dapat membentuk perilaku konsumen dalam memberikan sebuah tanggapan pada produk yang disukai dan tidak disukai. Tanggapan atau persepsi yang dirasakan oleh konsumen terdapat pada komponen pembentukan sikap yaitu komponen kognitif. Komponen kognitif menurut Ktech dan Crutcbfield (dalam Saladin, 2005) merupakan komponen kepercayaan yang didasari oleh pengetahuan, pengalaman dan persepsi seseorang mengenai suatu objek.

Nilai merupakan segala hal yang dianggap penting bagi setiap individu atau masyarakat. Menurut Sumarwan (2011) sebuah nilai akan berlangsung lama dan sulit berubah, hal ini kemudian akan memengaruhi pada sikap dan perilaku dalam pengambilan keputusan. Nilai konsumen (consumer value) merupakan nilai yang dirasakan selama dan/atau sesudah penggunaan dari sebuah produk (Rivière \& Mencarelli, 2012). Nilai konsumen ini dapat dipersepsikan berbeda-beda setiap individunya. Sebuah persepsi yang dihasilkan oleh konsumen terhadap suatu produk atau jasa dapat meningkatkan penjualan produk, karena persepsi didukung oleh adanya harapan konsumen terhadap produk tersebut. Sebagaimana definisi persepsi menurut Kotler dan Keller (2016) merupakan proses dalam memilih, mengatur, dan menerjemahkan masukan informasi untuk menciptakan persepsi yang tidak hanya berfokus pada stimuli fisik tetapi juga stimuli interpersonal dan lingkungan sekitar. Ketika konsumen dapat memenuhi kebutuhannya, maka perusahaan sudah mendapatkan sebuah nilai dari apa yang telah diberikan pada konsumen untuk masa waktu yang lama (Sweeney dan Soutar, 2001). Akan tetapi sebelum perusahaan ingin menambahkan nilai lebih pada produk yang ditawarkan perlu dipahami nilai apa yang dihargai oleh konsumen.

Menurut Mencarelli dan Rivie`re (2014) pengukuran terhadap perceived value yang paling efektif untuk dilakukan pada bisnis B2C adalah pendekatan analytical multidimensional conceptualization of value. Pendekatan ini dikatakan efektif karena sebuah nilai dapat diuku secara mendalam dari berbagai macam sumber penilaian karena perubahan nilai yang dirasakan oleh konsumen seiring waktu.

Menurut Sweeney \& Soutar (2001) perceived value yang dirasakan oleh konsumen dapat diukur dengan empat dimensi yaitu, emotional value, social value, quality/performance value, dan price/value for money value. Adapun penjelasan dari dimensi-dimensi perceived value tersebut sebagai berikut:

1. emotional value (nilai emosional) merupakan penilaian akan persepsi emosi yang dirasakan sepanjang pengalaman konsumsi sebuah produk yang diidentifikasi oleh berbagai pengalaman.

2. social value (nilai sosial) merupakan penilaian persepsi yang diperoleh dari adanya manfaat produk dalam peningkatan sosial konsumen.

3. quality/performance value (nilai kualitas/kinerja) merupakan penilaian persepsi antara ekspektasi kualitas juga kinerja produk.

4. price/value for money value (harga/nilai uang) merupakan utilitas yang diperoleh dari produk oleh adanya pengaruh biaya jangka panjang dan pendek.

\subsection{Repurchase Intention}

Niat pembelian merupakan pembelian yang sudah direncakan karena ada niat yang terbentuk untuk membeli sebuah produk. Adanya minat pembelian secara berulang biasanya menandakan bahwa produk tersebut sesuai dengan persetujuan konsumen dan bahwa dia bersedia menggunakannya lagi dan dalam jumlah yang lebih banyak (Schiffman dan Kanuk, 2004). Sedangkan menurut Hicks, et al (2005) repurchase intention adalah tindakan yang didasarkan pada kemungkinan konsumen akan mendapatkan produk yang sama atau produk yang baru akan diperhitungkan berdasarkan pengalaman pembelian 
sebelumnya. Kemudian repurchase intention menurut Hellier, et al (2003) merupakan sebuah penilaian individu tentang membeli kembali dari perusahaan yang sama dengan mempertimbangkan situasi saat ini dan keadaan lainnya yang memungkinkan terjadinya pembelian kembali akan produk atau layanan tersebut.

Hipotesis yang dilakukan dalam penelitian ini adalah:

H0: Tidak terdapat pengaruh positif yang signifikan antara perceived value terhadap repurchase intention produk sepatu.

Ha: Terdapat pengaruh positif yang signifikan antara perceived value terhadap repurchase intention produk sepatu.

\section{Metode Penelitian}

Penelitian ini dilakukan pada 100 konsumen yang pernah melakukan minimum satu kali pembelian produk sepatu Brodo di offline store Bandung. Teknik pengambilan sampel yang digunakan berupa purposive sampling dengan syarat a) pembelanjaan minimal satu kali dan memiliki pengalaman menggunakan produk dalam kurun waktu satu tahun terakhir (Januari 2017 - Mei 2018), b) usia minimal 20 tahun, karena sesuai dengan target pasar perusahaan bagi konsumen pria dewasa, c) konsumen khusus pria, karena perusahaan berfokus pada fashion bagi pria. Konsumen tidak diketahui populasinya secara pasti, oleh karena itu digunakan penentuan sampel menurut Cooper dan Schindler (2006).

Jenis penelitian yang dilakukan berupa ekplanasi (penjelasan), yakni penelitian deskriptif yang bertujuan untuk memaparkan variabel akan yang diteliti dan hubungan antarvariabel. Jenis pendekatan yang dilakukan adalah pendekatan kuantitatif yang menekankan pada interpretasi fakta-fakta deskripsi statistik, penafsiran dan peramalan hasil (Siregar, 2015).

Pengukuran variabel perceived value dan repurchase intention menggunakan kuesioner tertutup yang sudah berupa pilihan ganda. Skala pengukuran dalam kuesioner penelitian ini menggunakan 5 skala Likert positif dan negatif untuk jawaban "setuju". Pernyataan positif diberi skor 5,4,3,2,1, sedangkan bentuk negatif diberi skor 1,2,3,4,5.

Pengukuran dalam penelitian ini dapat dilihat pada kerangka penelitian yang ditunjukkan pada gambar 1. Teori yang digunakan pada variabel perceived value berasal dari Sweeney dan Soutar (2001) terdiri dari empat dimensi, yaitu emotional value, social value, functional value (price/value for money), dan functional value (performance/quality). Sedangkan teori yang digunakan untuk mengukur variabel repurchase intention dari Hellier, et al (2003).

Hasil uji validitas pada 100 responden pada variabel perceived value dan repurchase intention melebihi nilai $r$ tabel $(>0,1654)$. Selain itu, reliabilitas kedua variabel dapat dikatakan reliabilitasnya dapat diterima atau sangat reliabel dengan keandalan melebihi 0,6 (Perceived value: 0,934 > 0,6; Repurchase Intention: 0,826 > 0,6).

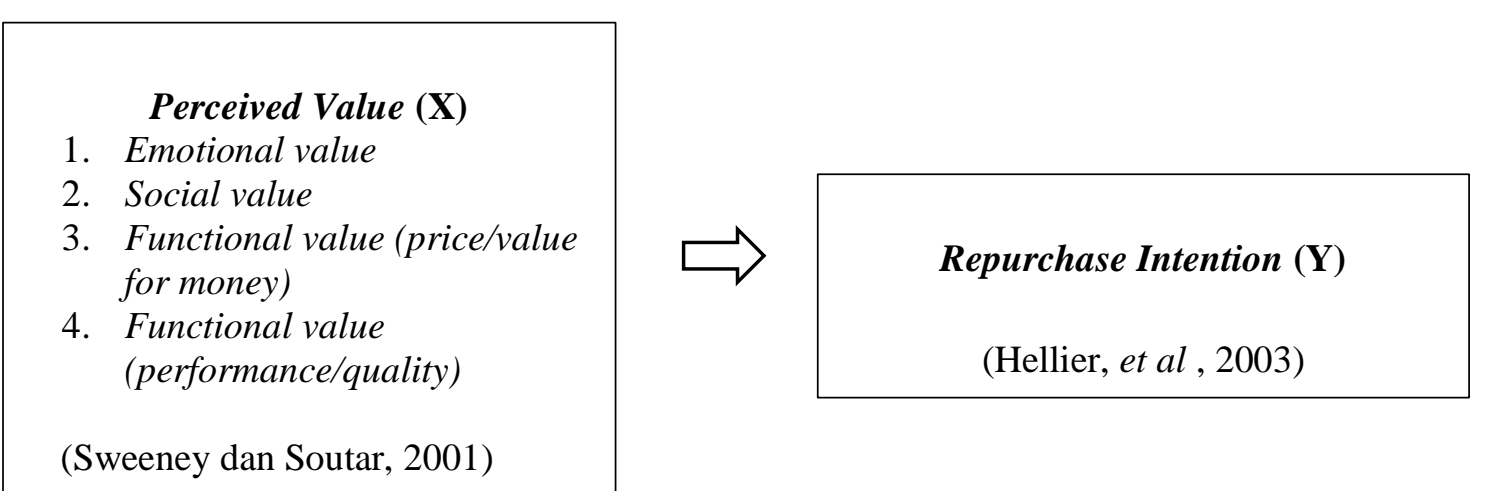

Gambar 1. Kerangka Pemikiran 


\section{Hasil dan Pembahasan}

\subsection{Profil Responden}

Usia responden rata-rata berada pada usia dewasa muda (20 - 34 tahun), yaitu 85\% di mana konsumen pada usia ini memiliki kebutuhan akan fashion yang dipengaruhi oleh perubahan gaya hidup. Kemudian responden memiliki status marital dengan rata-rata terbesar adalah sudah menikah sebesar 59\%. Pekerjaan yang dimiliki oleh konsumen paling banyak adalah pegawai swasta dengan persentase sebesar 49\%, sedangkan pendidikan terakhir mayoritas responden adalah 59\% sarjana yang mengindikasikan bahwa responden memiliki pendidikan yang tinggi. Pendapatan per bulan yang dihasilkan oleh responden memiliki daya beli tinggi karena sebanyak $74 \%$ responden berpenghasilan di atas Rp 3.500.000 atau berarti mayoritas responden berada pada perekonomian menengah ke atas. Intensitas pembelian yang dilakukan oleh responden minimum satu kali pembelian dengan persentase tertinggi 52\% pada jenis sepatu kantor.

\subsection{Analisis Deskriptif}

Berdasarkan tabel 2 dapat diketahui bahwa nilai rata-rata variabel perceived value sebesar 4,08 yang termasuk pada interval 3,41-4,20. Nilai ini menunjukkan bahwa persepsi nilai yang dirasakan oleh konsumen PT Brodo Ganesha Indonesia di Offline Store Bandung termasuk pada kategori tinggi. Variabel perceived value memiliki empat dimensi yang terdiri dari emotional value, social value, price value, dan quality value. Nilai rata-rata tertinggi berada pada dimensi emotional value yaitu 4,24 yang termasuk sangat tinggi. Pernyataan pada indikator ini menandakan bahwa konsumen sangat menyukai jenis-jenis sepatu yang diperjualbelikan oleh Brodo offline store Bandung. Sedangkan nilai rata-rata terendah pada variabel ini adalah dimensi price value yaitu sebesar 3,96 dan berada pada interval 3,41 - 4,20 yang berarti termasuk pada kategori tinggi. Hal ini berisikan tentang harga sepatu yang ditawarkan termasuk hemat atau ekonomis. Kemudian nilai standar deviasi variabel perceived value sebesar 0,703 atau 17,3\% yang menunjukkan angka di bawah $20 \%$. Hal tersebut menjelaskan bahwa tingkat keberagaman akan pilihan jawaban responden adalah rendah.

Tabel 2. Statistik Deskriptif Perceived Value

\begin{tabular}{|l|c|c|c|c|c|}
\hline & N & Min & Max & Mean & Std. Dev \\
\hline Emotional Value & 100 & 2 & 5 & 4.24 & 0.607 \\
\hline Social Value & 100 & 1 & 5 & 4.02 & 0.751 \\
\hline Price Value & 100 & 1 & 5 & 3.96 & 0.761 \\
\hline Quality Value & 100 & 2 & 5 & 4.09 & 0.694 \\
\hline
\end{tabular}

Pada variabel repurchase intention terdapat sejumlah informasi yang dapat diperoleh dalam tabel 3. Nilai rata-rata pada variabel ini berada pada kategori tinggi dengan angka sebesar 3,78 dan berada pada interval 3,41 - 4,20. Adapun nilai rata-rata tertinggi ditunjukkan oleh item repurchase intention 1 sebesar 3,99 yang termasuk ke dalam kategori tinggi. Pernyataan pada item ini menunjukkan bahwa adanya keinginan yang tinggi untuk menggunakan sepatu Brodo yang dijual oleh offline store. Hal ini menjelaskan bahwa konsumen yang sudah pernah membeli dan menggunakan sepatu Brodo memiliki keinginan untuk mengonsumsi kembali produk yang sama.

Sedangkan nilai rata-rata terendah terletak pada item repurchase intention 2 sebesar 3,64 dan termasuk ke dalam kategori yang tinggi yaitu pada interval 3,41 - 4,20. Pernyataan pada item ini menjelaskan tentang keinginan konsumen untuk membeli sepatu Brodo dalam jumlah lebih banyak dalam beberapa tahun ke depan. Nilai standar deviasi repurchase intention menunjukkan angka sebesar 0,730 atau dalam persentase sebesar 19,31\%. Angka tersebut berada di bawah angka $20 \%$ yang memiliki arti bahwa sebaran data responden pada variabel ini memiliki tingkat keberagaman yang rendah. 
Tabel 3. Statistik Deskriptif Repurchase Intention

\begin{tabular}{|l|c|c|c|c|c|}
\hline & $\mathbf{N}$ & Min & Max & Mean & Std. Dev \\
\hline Repurchase Intention_1 & 100 & 2 & 5 & 3.99 & 0.628 \\
\hline Repurchase Intention_2 & 100 & 1 & 5 & 3.64 & 0.798 \\
\hline Repurchase Intention_3 & 100 & 1 & 5 & 3.73 & 0.763 \\
\hline Repurchase Intention & 100 & 1 & 5 & 3.78 & 0.730 \\
\hline
\end{tabular}

Berdasarkan tabel 4 dapat diketahui bahwa nilai uji korelasi menunjukkan angka 0,688 dan berada pada interval 0,600 - 0,799. Dengan demikian, korelasi pada penelitian ini tergolong kuat dan menunjukkan nilai yang positif atau berarti terdapat hubungan yang searah. Apabila perceived value mengalami peningkatan maka repurchase intention pun akan mengikuti kenaikannya.

Tabel 4. Hasil Uji Korelasi

\begin{tabular}{|c|c|c|c|}
\hline \multirow{3}{*}{ Perceived Value } & & PV & RI \\
\hline & Pearson Correlation & 1 & $0.688^{* *}$ \\
\hline & Sig. (2-tailed) & & 0.000 \\
\hline & $\mathrm{N}$ & 100 & 100 \\
\hline \multirow[t]{3}{*}{ Repurchase Intention } & Pearson Correlation & $0.688^{* *}$ & 1 \\
\hline & Sig. (2-tailed) & 0.000 & \\
\hline & $\mathrm{N}$ & 100 & 100 \\
\hline
\end{tabular}

Berdasarkan tabel 5 didapatkan nilai konstanta sebesar 0,144 dan koefisien regresi sebesar 0,144, maka persamaan regresi pada peneliatian ini adalah $\mathrm{Y}=0,144+0,144 \mathrm{X}$. Persamaan tersebut menunjukkan apabila terjadi peningkatan pada perceived value sebesar 1 satuan, repurchase intention akan bertambah sebanyak 0,144 kali.

Tabel 5. Hasil Uji Regresi Linear

\begin{tabular}{|l|l|l|l|l|l|l|}
\hline \multicolumn{2}{|l|}{ Model } & Unstd. Coef. & Std. Coef. & t & Sig. \\
\cline { 3 - 8 } & B & Std. Error & Beta & & \\
\hline \multirow{2}{*}{1} & $($ Constant $)$ & 0.144 & 1.203 & & 0.120 & 0.905 \\
\cline { 2 - 8 } & PV & 0.144 & 0.015 & 0.688 & 9.382 & 0.000 \\
\hline \multicolumn{2}{|l|}{ a. Dependent Variable: Repurchase Intention } \\
\hline
\end{tabular}

Berdasarkan tabel 5 dapat diketahui nilai "R square" sebesar 0,473 menunjukkan bahwa perceived value dapat memengaruhi repurchase intention sebesar 47,3\%. Kemudian 52,7\% dipengaruhi oleh faktor lainnya yang tidak dikaji dalam penelitian ini.

Tabel 6. Hasil Uji Koefisien Determinasi

\begin{tabular}{l|l|l|r|r|}
\hline Model & R & R Square & Adjusted R Square & Std. Error of the Estimate \\
\hline 1 & $0.688^{a}$ & 0.473 & 0.468 & 1.382 \\
\hline
\end{tabular}
a. Predictors: (Constant), Perceived Value
b. Dependent Variable: Repurchase Intention

\subsection{Uji Hipotesis}

Berdasarkan tabel 7 dapat diketahui bahwa nilai $F_{\text {hitung }}$ sebesar 88,022 dengan signifikansi 0,000 memiliki angka lebih besar dibandingkan dengan $F_{\text {tabel }}$ nya 3,938111. Kemudian, nilai signifikansi yang menunjukkan angka di bawah standar $(0,000<0,05)$ dapat diartikan bahwa perceived value berpengaruh secara signifikan terhadap repurchase intention produk sepatu pada konsumen PT Brodo Ganesha Indonesia di Offline Store Bandung. 
Tabel 7. Hasil Uji Statistik F

\begin{tabular}{|l|l|r|c|c|}
\hline \multicolumn{2}{|l|}{ Model } & \multicolumn{1}{c|}{ df } & \multicolumn{1}{c|}{ F } & Sig. \\
\hline \multirow{2}{*}{1} & Regression & 1 & 88.022 & $0.000^{\mathrm{b}}$ \\
\cline { 2 - 5 } & Residual & 98 & & \\
\cline { 2 - 5 } & Total & 99 & & \\
\hline
\end{tabular}

Berdasarkan tabel 8 dapat diketahui nilai $t_{\text {hitung }}$ sebesar 9,382 dengan signifikansi 0,000 memiliki angka lebih besar dibandingkan dengan $t_{\text {tabel }}$ sebesar 1,660551. Kemudian, nilai signifikansi yang menunjukkan angka di bawah standar $(0,000<0,05)$ dapat diartikan bahwa perceived value berpengaruh secara signifikan terhadap repurchase intention produk sepatu pada konsumen PT Brodo Ganesha Indonesia di Offline Store Bandung.

Tabel 8. Hasil Uji Statistik t

\begin{tabular}{|l|l|r|r|}
\hline \multicolumn{2}{|l|}{ Model } & \multicolumn{1}{|l|}{ t } & \multicolumn{1}{c|}{ Sig. } \\
\hline \multirow{2}{*}{1} & (Constant) & 0.120 & 0.905 \\
\cline { 2 - 4 } & PV & 9.382 & 0.000 \\
\hline
\end{tabular}

\subsection{Pengaruh Perceived Value Terhadap Repurchase Intention}

Berdasarkan hasil penelitian yang diujikan pada 100 konsumen Brodo Offline Store Bandung dapat diketahui bahwa terdapat adanya hubungan yang kuat positif antara perceived value terhadap repurchase intention. Hal tersebut didapatkan dari hasil uji korelasi yang memiliki nilai sebesar 0,688 dan berada pada interval 0,60-0,799. Hubungan bersifat positif karena terjadi hubungan searah antara kedua variabel. Apabila nilai terhadap produk sepatu semakin terpatri dalam diri konsumen, maka tingkat keinginan pembelian ulang sepatu akan semakin bertambah.

Hasil uji linier sederhana menunjukkan persamaan $Y=0,144+0,144 X$ dengan signifikansi $(0,000)$ di bawah 0,05 yang memiliki arti bahwa terdapat adanya pengaruh positif perceived value terhadap repurchase intention. Persamaan linier tersebut memiliki nilai konstanta sebesar 0,144 yang menunjukkan apabila terjadi kenaikan pada satu persen nilai perceived value, maka terjadi penambahan/kenaikan nilai repurchase intention sebesar 0,144 .

Hasil uji hipotesis yang dilakukan pada penelitian ini menerima Ha dan menolak $\mathrm{H} 0$ yang diperoleh dari hasil uji $F$ dan uji t. Pada uji $F$ dihasilkan nilai $F_{\text {hitung }}$ melebihi nilai $F_{\text {tabel }}(88,022>3,938111)$ dengan signifikansi 0,000 di bawah 0,05 dengan demikian dapat dikatakan terdapat pengaruh positif yang signifikan antara perceived value terhadap repurchase intention. Kemudian pada uji t diperoleh nilai $\mathrm{t}_{\text {hitung }}$ melebihi nilai $\mathrm{t}_{\text {tabel }}(9,382>1,660551)$ dengan signifikansi 0,000 di bawah 0,05 dengan demikian ada pengaruh positif yang signifikan perceived value terhadap repurchase intention.

Hasil koefisien determinasi menunjukkan nilai $\mathrm{R}$ square sebesar 0,473 atau dalam artian perceived value dapat memberikan pengaruh terhadap repurchase intention sebanyak $47,3 \%$. Sebanyak $52,7 \%$ lainnya dipengaruhi oleh faktor-faktor lain yang tidak diujikan pada penelitian ini. Beberapa faktor tersebut meliputi brand preference, expected switching cost, customer loyalty, customer satisfaction, perceived equity, dan perceived quality (Hellier, et al).

Perceived value dapat menjadi variabel untuk memprediksi terciptanya repurchase intention. Apabila nilai yang dirasakan konsumen lebih besar dari biaya yang dirasakan karena memiliki produk, konsumen akan selalu memiliki kecenderungan positif untuk membeli kembali (Ahmed, 2014).

\section{Kesimpulan dan Saran}

\subsection{Kesimpulan}

Berdasarkan hasil dari pengumpulan data dari 100 konsumen yang menggunakan sepatu Brodo di offline store Bandung dan pembahasan yang diolah dengan bantuan SPSS 22.0, maka kesimpulan dapat diketahui sebagai berikut: 
1. Perceived value yang dirasakan oleh konsumen Brodo di offline store Bandung tergolong tinggi. Dimensi emotional value memiliki nilai rata-rata tertinggi dan berada pada kategori sangat tinggi. Sedangkan functional value of price memiliki nilai rata-rata terendah, namun termasuk pada kategori tinggi.

2. Repurchase intention atas produk sepatu Brodo di offline store Bandung termasuk dalam kategori tinggi. Nilai rata-rata tertinggi berada pada indikator pertama adalah pembelian produk secara berulang, sedangkan nilai rata-rata terendah berada pada indikator kedua yakni pembelian dalam kuantitas yang lebih banyak.

3. Diketahui bahwa terdapat pengaruh yang signifikan antara perceived value terhadap repurchase intention produk sepatu pada konsumen PT Brodo Ganesha Indonesia di offline store Bandung sebesar 47,3\%. Kemudian pengaruh lainnya sebesar 52,7\% disebabkan oleh faktor-faktor lain yang tidak dikaji pada penelitian ini seperti brand preference dan customer satisfaction.

\subsection{Saran}

Berikut ini merupakan saran yang dapat diberikan.

1. Persepsi nilai yang dirasakan oleh konsumen perlu ditingkatkan pada aspek price value. Oleh karena itu, perusahaan sebaiknya penciptaan nilai bagi konsumen dengan klasifikasi harga pada segmentasi pasar yang berbeda. Hal ini dapat dikaitkan dengan gaya hidup, pendapatan, pendidikan dan latar belakang konsumen. Adapun dengan cara menawarkan harga normal namun kualitas standar (dapat diterima kualitasnya sebagai pelindung kaki saja) bagi konsumen kelas menengah ke bawah. Sedangkan produk untuk kelas menengah ke atas, menawarkan harga yang lebih tinggi dengan kualitas premium. Sepatu ditempatkan pada rak yang terpisah dengan pemberian informasi mengenai kelebihan produk dari segi kualitas. Namun tetap pada prinsip menghantarkan price value perusahaan dengan tidak mencantumkan label harga pada produk.

2. Repurchase intention yang masih harus rendah berada pada pembelian dalam kuantitas yang lebih banyak. Sebaiknya perusahaan dianjurkan untuk memperbaiki manajemen rantai pasokan dengan cara membentuk koordinasi kerja tim yang disebut concurrent engineering. Koordinasi kerja tim ini melibatkan pembahasan dan pembuatan keputusan dengan kesesuaian persediaan produk bagi segmentasi konsumen berdasarkan kebutuhan. Seperti contohnya adalah meningkatkan persediaan sepatu dengan ukuran nomor sepatu 40 sampai dengan 42 karena tingginya tingkat permintaan sepatu dengan ukuran tersebut hampir untuk semua jenis produk sepatu yang ditawarkan.

\section{Daftar pustaka}

Ahmed, S. (2014). From Customer Perceived Value to Repurchase Intention in Textile Sector of Bangladesh: A Correlation Study. International Journal of Ethics in Social Sciences, 2(1), 59-72.

BPS. (2018, February 25). Konsumsi dan Pengeluaran » Persentase Pengeluaran Rata-rata per Kapita Sebulan Menurut Kelompok Barang, Indonesia, 1999, 2002-2016. Retrieved from Badan Pusat Statistik: https://www.bps.go.id/statictable/2009/06/15/937/persentase-pengeluaran-rata-rata-perkapita-sebulan-menurut-kelompok-barang--indonesia--1999--2002-2016.html

Cooper, D. R., \& Emory, C. W. (1998). Business Research Methods 5th Edition. Diterjemahkan oleh Widyono $S$ dan Uka W. Jakarta: Erlangga.

Hawkins, D. I., \& Mothersbaugh, D. L. (2010). Consumer Behavior: Building Marketing Stategy Eleventh Edition. New York: McGraw-Hill/Irwin.

Hellier, P. K., Geursen, G. M., Carr, R. A., \& Rickard, J. A. (2003). Customer Repurchase Intention: A General Structural Equation Model. European Journal of Marketing, 37(11/12), 1762-1800.

Hicks, J. M., \& et al (2005). Delighted Consumers Buy Again. Journal of Consumer Satisfaction, Dissatisfaction and Complaining Behavior, 18(1), 94-104.

Huang, C.-L. (2015). The Influence of Perceived Value on Repurchase Intention: A Leading 3C Retailer in Taiwan as an Example. International Journal of Information Technology and Business Management, 43(1), 2304-2337.

Kotler, P., \& Keller:, K. L. (2016). Marketing Management 16th Edition. New Jersey: Pearson.

Rivière, A., \& Mencarelli, R. (2012). Towards a Theoretical Clarification of Perceived Value on Marketing. Recherche et Applications en Marketing, 27(1), 97-122.

Saladin, D. (2005). Perilaku Konsumen dan Pemasaran Strategik. Bandung: Agung Ilmu. 
Schiffman, L. G., \& Kanuk, L. L. (2004). Customer Behavior, 8th Edition. New Jersey: Pearson Prentice Hall.

Siregar, S. (2015). Statistik Parametrik untuk Penelitian Kuantitatif. Jakarta: Bumi Aksara

Sumarwan, U. (2011). Perilaku Konsumen (Teori dan Penerapannya dalam Pemasaran). Bogor: Ghalia Indonesia.

Suyani, T. (2013). Perilaku Konsumen di Era Internet. Yogyakarta: Graha Ilmu.

Sweeney, J. C., \& Soutar, G. N. (2001). Consumer perceived value: The development of a multiple scale item. Journal of Retailing, 77(1), 203-220.

Wikipedia. (2018, March 11). Industri Kreatif. Diambil dari Wikipedia Ensiklopedia Bebas: https://id.wikipedia.org/wiki/Industri_kreatif.

*Email korespondensi:

9a.rika@gmail.com 